\title{
Rancang Bangun Prototipe Pengendalian Lengan Robot (Robotic Arm) sebagai Pemindah Barang Berbasis Internet Of Things
}

\author{
Syah Alam ${ }^{1}$, Gunawan Tjahjadi ${ }^{2}$, Nur Rahma Yenita ${ }^{3}$, Supriyadi $^{4}$ \\ ${ }^{1,2}$ Department of Electrical Engineering, Universitas Trisakti, Indonesia \\ ${ }^{3,4}$ Department of Electrical Engineering, Sekolah Tinggi Teknologi Indonesia, Indonesia
}

\begin{tabular}{l}
\hline Article Info \\
\hline Article history: \\
Received May 29, 2021 \\
Revised Sep 18, 2021 \\
Accepted Sep 29, 2021 \\
\hline
\end{tabular}

\section{Keywords:}

Arm Robot

Internet of Things

NodeMCU

Motor Servo

Microcontroller

\begin{abstract}
This study proposes a prototype design of a robot arm control system based on the Internet of Things (IoT) by utilizing the NodeMCU microcontroller and the Blynk application. The NodeMCU microcontroller functions as a control system combined with four servo motors that are positioned as mechanical drives at the base, shoulder, elbow, and grip of the robot arm. The angle settings of each motor are $180^{\circ}, 90^{\circ}, 60^{\circ}$, and $90^{\circ}$ which are used as actuators for lifting, gripping, and moving loads. To control the robotic arm, the blynk application can be accessed via smartphone. From the results of the design and testing, it was found that the maximum load that could be moved was 20 grams with a transfer time of 46 seconds and a speed of 0.0054 seconds. The maximum distance for moving goods is $25 \mathrm{~cm}$ and the types of goods being moved are those that have a rough surface. This research is useful as a solution for moving goods that can be controlled remotely
\end{abstract}

Copyright $\odot 2020$ Universitas Indraprasta PGRI. All rights reserved.

\section{Corresponding Author:}

Syah Alam,

Department of Electrical Engineering,

Universitas Trisakti,

Jl. Kyai Tapa No.1, Grogol, Jakarta Barat.

Email:syah.alam@trisakti.ac.id

\section{PENDAHULUAN}

Perkembangan teknologi telah berhasil mengalami era evolusi baru serta memasuki industri 4.0 atau yang dikenal sebagai Internet of Things (IoT) dan Robotic. Internet of Things (IoT) adalah jaringan dari bendabenda fisik, seperti perangkat, kendaraan, bangunan dan barang-barang lainnya yang memiliki perangkat elektronik, perangkat lunak, sensor dan konektivitas jaringan internet, memungkinkan benda-benda tersebut mengumpulkan dan melakukan pertukaran data [1] [2] . Robot digambarkan sebagai mesin yang dirancang untuk melakukan tugas tertentu berdasarkan program yang dibuat oleh pengguna [3] [4] [5]. Selain itu, robot memungkinkan mampu menjalankan beberapa proses dalam waktu bersamaan. Robot paling umum digunakan untuk keperluan industri adalah lengan robot (Robot Arm).

Saat ini, penggunaan robot manipulator semakin luas karena kepresisiannya, mampu mengerjakan satu pekerjaan secara berulang-ulang, dan karena ketahanannya terhadap kondisi lingkungan yang ekstrim [6] [7] [8]. Mereka biasanya diterapkan dalam tugas perakitan berulang, dimana semua komponen selalu dalam posisi yang sama dan hanya diperlukan kontrol posisi robot. Namun demikian, penerapan robot manipulator dapat meningkatkan produktivitas proses industri saat ini.

Penelitian yang diusulkan oleh [9] berhasil lengan robot yang dikendalikan secara jauh dengan menggunakan bluetooth dengan jarak maksimal 10 meter tanpa halangan sedangkan pada penelitian yang dilakukan oleh [10] lengan robot direalisasikan dengan menggunakan pengendali jarah jauh menggunakan joystick. Namun, kedua penelitian diatas memiliki kekurangan dari penelitian tersebut adalah keterbatasan 
jarak dari sistem pengendalian lengan robot yang dirancang. Pendekatan yang dilakukan dalam penelitian ini adalah melakukan optimasi jarak pengendalaian dan merancang sistem yang dapat memastikan pemindahan barang dari satu tempat ke tempat yang lain dengan menggunakan kamera. Penelitian ini mengusulkan desain lengan robot yang dapat dikendalikan secara jarak jauh menggunakan jaringan internet dan dapat dikendalikan menggunakan aplikasi blynk. Penggunaan Internet of Things bertujuan untuk mendapatkan jarak kendali yang lebih optimal sedangkan penggunaan aplikasi blynk bertujuan untuk memudahkan sistem pengendalian sehingga dapat diakses menggunakan smartphone [11]. Selain itu, untuk meningkatkan kecepatan waktu pemindahan dan daya cengkram dari lengan robot digunakan empat buah motor servo yang berfungsi sebagai aktuator di bagian bawah, bahu, siku dan pencengkraman. Selanjutnya, dalam penelitian ini juga menambahkan modul kamera jenis ESP32 CAM yang berfungsi untuk merekam dan mendokumentasi pemindahan barang agar dapat dimonitor kondisi sebelum dan sesudah dipindahkan [12]. Kontribusi keilmuan dari penelitian ini adalah menghasilkan prototipe yang dapat diakses secara jarak jauh dengan jarak lebih dari 10 meter dan dapat termonitor secara langsung menggunakan kamera untuk memastikan proses pemindahan barang dari satu tempat ke tempat lain.

\section{METODE}

Perancangan desain sistem diperlukan untuk memudahkan dalam pembuatan prototipe. Dalam perancangannya, terdapat komponen-komponen yang dibutuhkan untuk prototipe lengan robot. Gambar 1 menunjukan tahapan dalam perancangan prototipe.

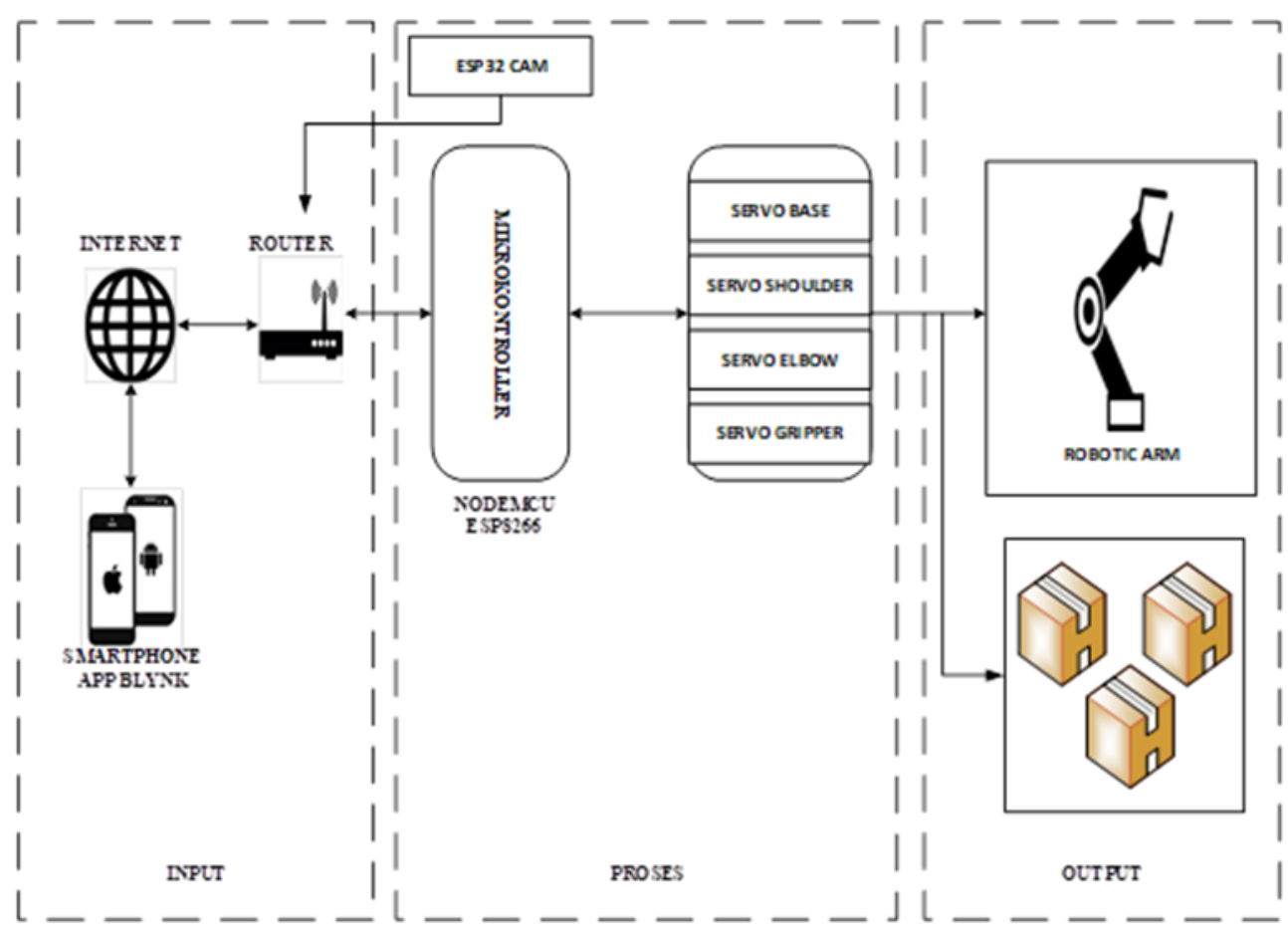

Gambar 1. Blok Diagram Sistem Pengendalian Lengan Robot

Pada gambar 1 terlihat bahwa terdapat satu akses untuk dapat mengendalikan prototipe tersebut, yaitu melalui smartphone. Prinsip kerja dari prototype ini adalah dapat mengendalikan robot lengan menggunakan internet. Pertama smartphone memberikan perintah melalui aplikasi blynk dengan melakukan koneksi melalui internet dan akan masuk melalui router yang selanjutnya akan diproses oleh kontroler yaitu NodeMCU dan kontroler akan mengolah data lalu mengirim sinyal ke aktuator dan aktuator dapat mengirimkan kondisi kembali ke kontroler. Selanjutnya, sinyal yang dikirimkan oleh kontroler kemudian diolah menjadi sebuah aksi dalam bentuk pergerakan lengan robot. Kontroler akan mengolah data tersebut dan akan meneruskan data tersebut ke internet dan akan ditampilkan pada aplikasi blynk pada smartphone, sedangkan ESP32 CAM 
menampilkan video streaming melaui IP address ataupun melalui aplikasi blynk dengan berupa foto atau gambar. Diagram alir proses pengendalian lengan robot ditunjukkan pada gambar 2.

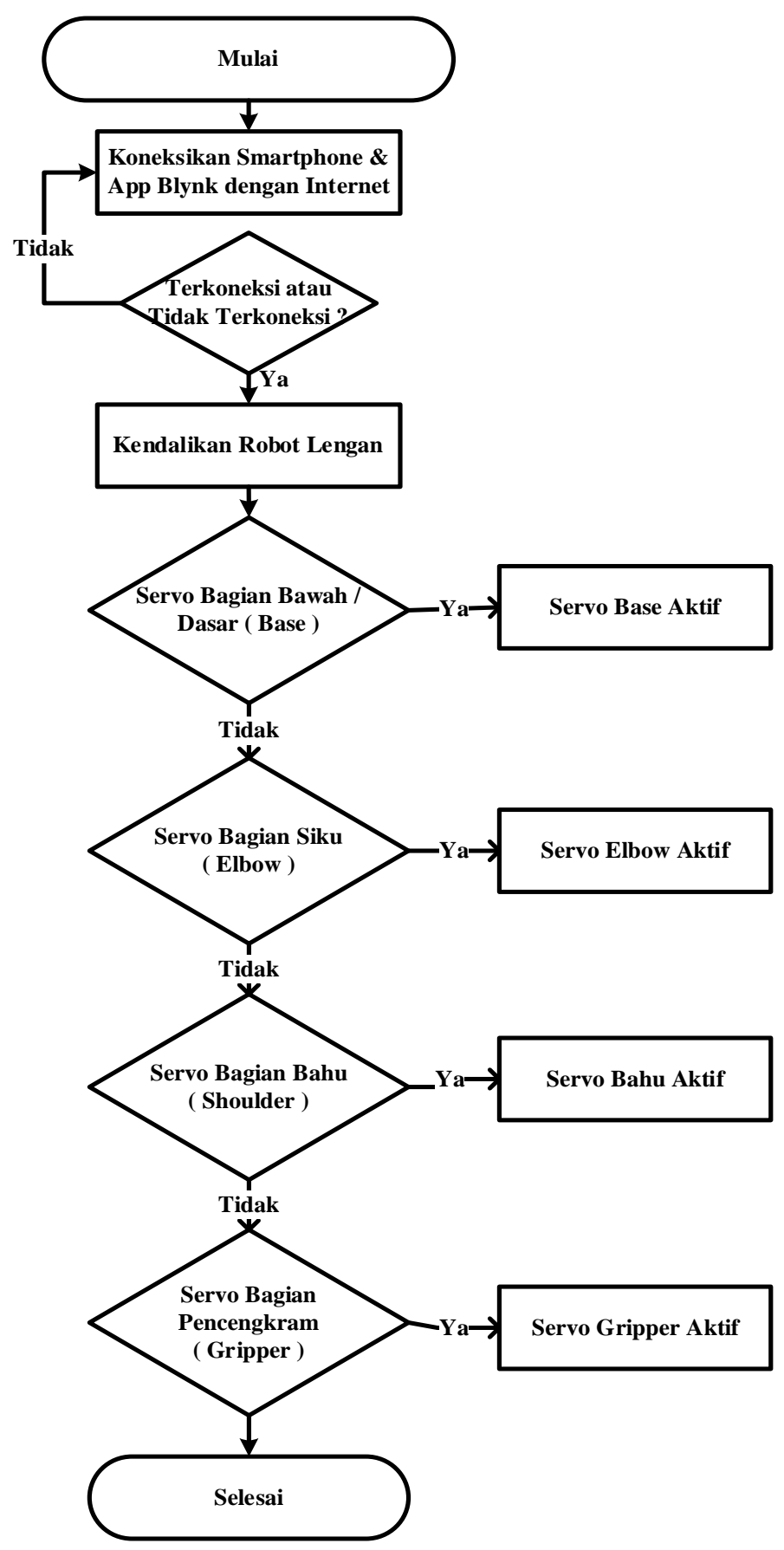

Gambar 2. Flowchart pengendalian prototype robotic arm

Gambar 2 menunjukkan diagram alir proses pengendalian lengan robot menggunakan aktuator motor servo yang terdiri dari empat bagian yaitu bagian bawah (base), siku (elbow), bahu (shoulder) dan pencengkram (gripper). Aktuator dikendalikan oleh mikrokontroller NodeMCU yang terkoneksi dengan jaringan intertet dan aplikasi blynk yang dapat di akses menggunakan smartphone. Keempat motor servo berfungsi untuk mengangkat, mencengkram dan memindahkan barang sesuai dengan target yang ditetapkan. Selanjutnya, gambar 3 menunjukkan diagram alir proses monitoring dari perpindahan barang menggunakan 
modul modul ESP52 CAM. Proses perpindahan barang dapat dimonitor secara langsung dalam bentuk video dan foto yang terkoneksi dengan jaringan internet dan mendapatkan IP adress dari router yang digunakan. Metode evaluasi yang digunakan adalah pengamatan secara langsung dan membandingkan dengan hasil perancangan yang telah dilakukan.

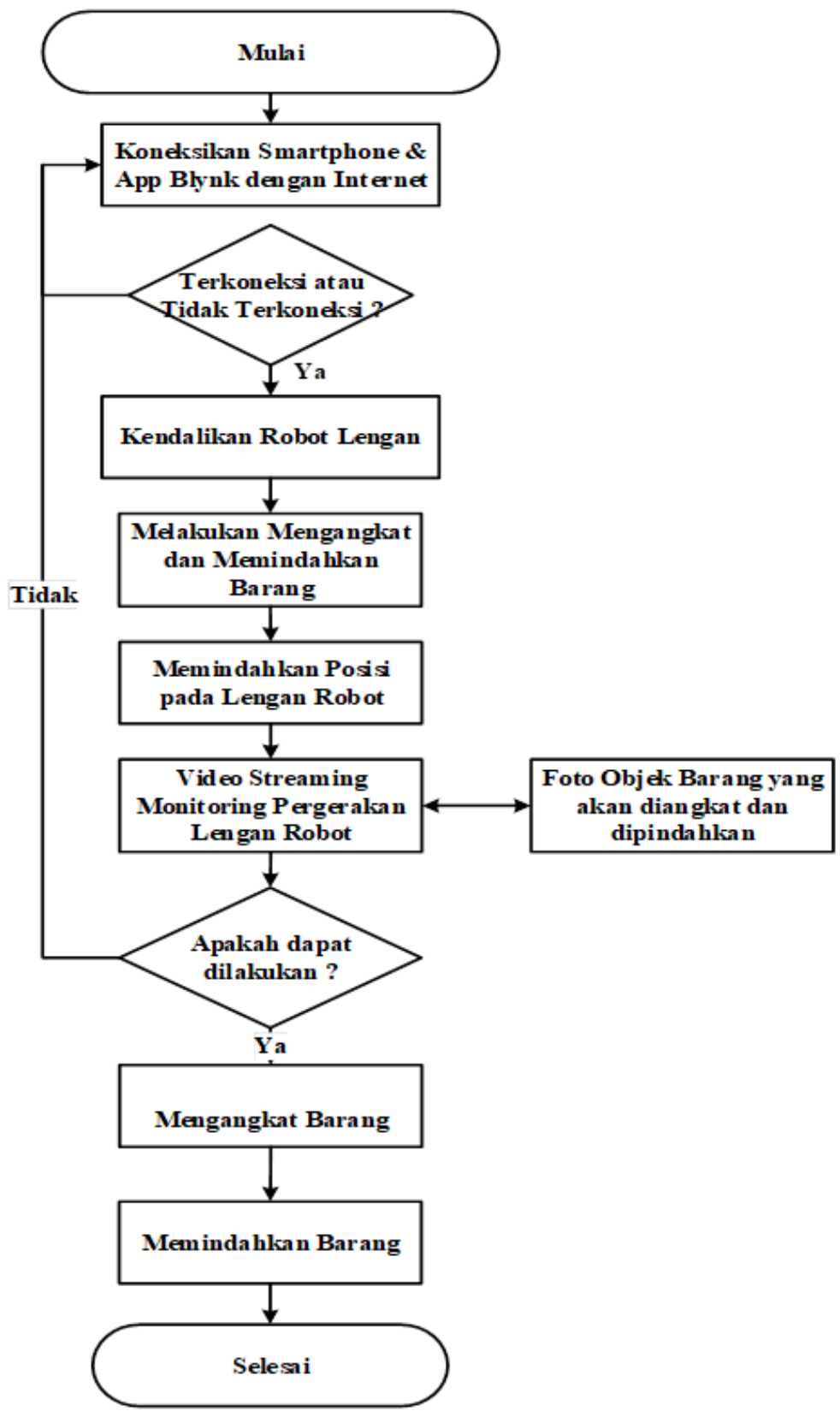

Gambar 3. Flowchart Pengangkatan dan Monitoring Barang prototype robotic

\section{HASIL DAN PEMBAHASAN}

\subsection{Struktur Mekanik Lengan Robot}

Struktur mekanik lengan robot disusun menggunakan empat buah motor servo sebagai aktuator di mana masing-masing motor servo diletakkan di tempat yang berbeda tergantung dari torsi yang di hasilkan oleh motor servo tersebut. Gambar 4 merupakan struktur mekanik lengan robot dimana empat bagian utama pada 
robot tersebut berperan sebagai penghubung (link), yang meliputi:

1. Bagian dasar/bawah (base)

2. Bagian bahu (shoulder)

3. Bagian siku (elbow)

4. Bagian pencengkeram (gripper)

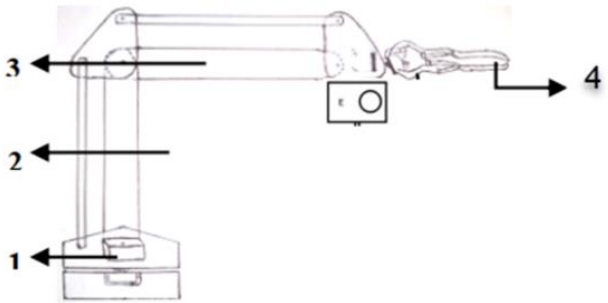

Gambar 4. Struktur Mekanik Lengan Robot

Motor servo bawah (base) berfungsi untuk menggerakkan lengan robot dengan sudut $0-180^{\circ}$ sedangkan untuk motor servo bahu (shoulder) berfungsi untuk menggerakan lengan robot dengan rentangan sudut $0-90^{\circ}$. Kedua servo tersebut berfungsi sebagai pengendali lengan robot dalam proses pengangkatan beban yang akan dipindahkan. Selanjutnya, motor servo bagian siku (elbow) berfungsi menggerakkan lengan robot dengan sudut $0-60^{\circ}$ sedangkan motor servo pencengkaraman (gripper) menggerakkan lengan robot dengan sudut $0-90^{\circ}$. Spesfikasi keempat motor servo yang digunakan pada lengan robot ditunjukkan pada Tabel 1 .

Tabel 1. Spesifikasi Motor Servo

\begin{tabular}{cccc}
\hline Lengan Penghubung & Dimensi & Sensitivitas Sudut & Sudut Maksimal \\
\hline Dasar (Base) & $9 \mathrm{~cm}$ & $0-180^{\circ}$ & $180^{\circ}$ \\
Bahu (Shoulder) & $14 \mathrm{~cm}$ & $0^{\circ}-90^{\circ}$ & $90^{\circ}$ \\
Siku (Elbow) & $13 \mathrm{~cm}$ & $0^{\circ}-60^{\circ}$ & $60^{\circ}$ \\
Penjepit (Gripper) & $7 \mathrm{~cm}$ & $0^{\circ}-90^{\circ}$ & $90^{\circ}$ \\
\hline
\end{tabular}

\subsection{Struktur Perangkat Keras}

Berdasarkan diagram blok sistem pada gambar 1, perangkat keras (hardware) yang digunakan dalam lengan robot adalah sebagai berikut:

1. Modul NodeMCU ESP8266 berfungsi sebagai mikrokontroler yang memproses dan mengolah data serta sebagai pengirim dan penerima data dari internet melalui wifi dengan aplikasi Blynk.

2. Empat motor servo pada lengan robot yang berfungsi sebagai aktuator pemindah barang.

3. Aplikasi Blynk pada smartphone Android yang berfungsi sebagai pengontrol jarak jauh.

4. Modul ESP32 CAM berfungsi sebagai monitoring pergerakan robot di saat akan mengangkat dan memindahkan barang.

Rangkaian skematik keseluruhan dan hubungan antara NodeMCU dengan komponen pendukung seperti motor servo dan ESP 32 CAM ditunjukkan pada gambar 5 dan gambar 6.

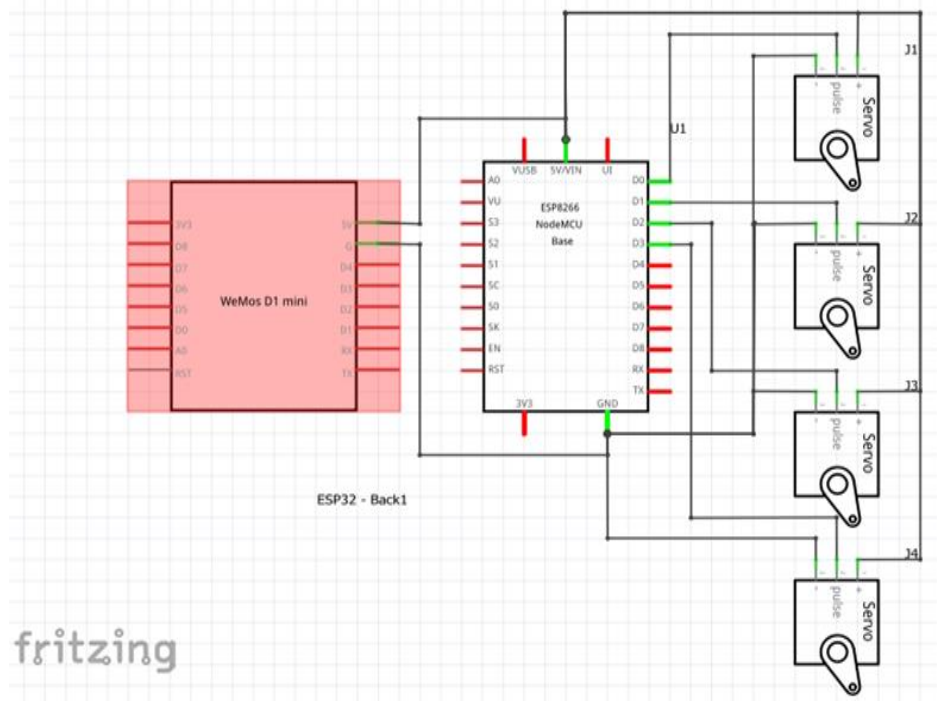


Gambar 5. Rangkaian Skematik Pengendali Lengan Robot

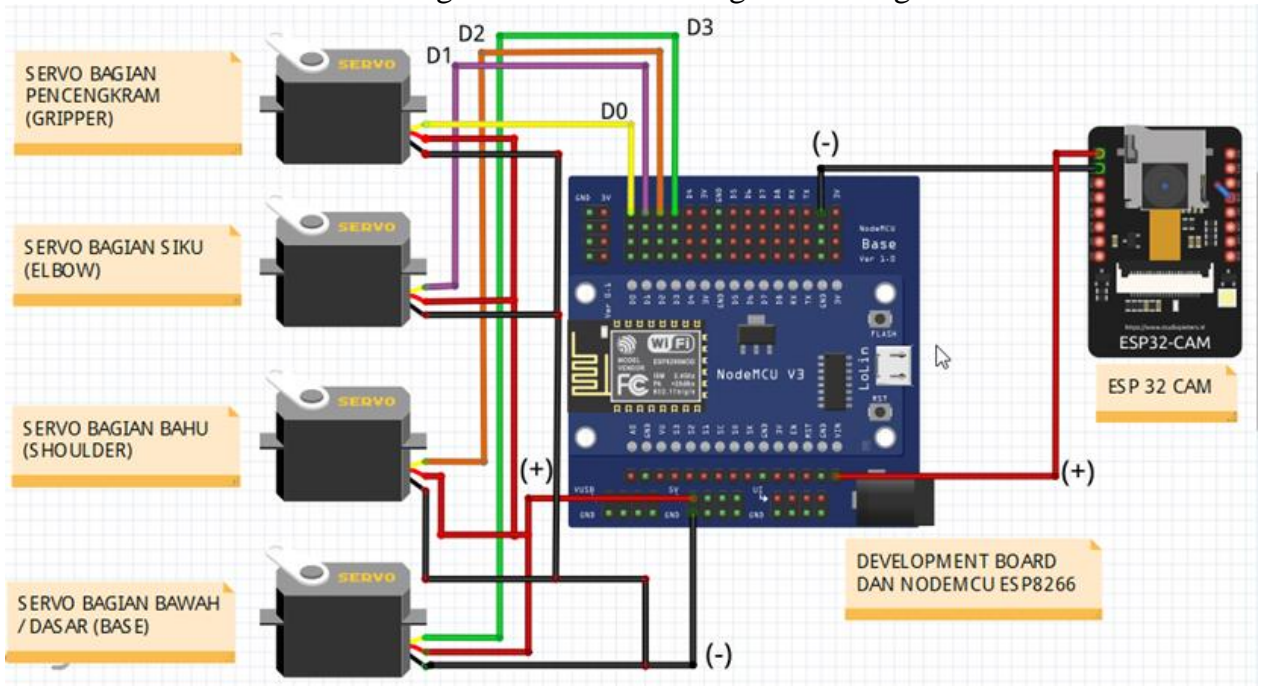

Gambar 6. Hubungan antara NodeMCU dengan motor servo dan ESP 32 CAM

\subsection{Perangkat Antar Muka (Interface)}

Untuk menggerakkan lengan robot dari jarak jauh melalui koneksi jaringan WiFi dapat memanfaatkan aplikasi yang sudah tersedia pada "Play store" android yaitu aplikasi "BLYNK". Aplikasi ini digunakan sebagai remote control untuk mengirimkan perintah ke lengan robot. Tahapan perancangan antarmuka untuk menggerakkan lengan robot ditunjukkan pada gambar 7 .

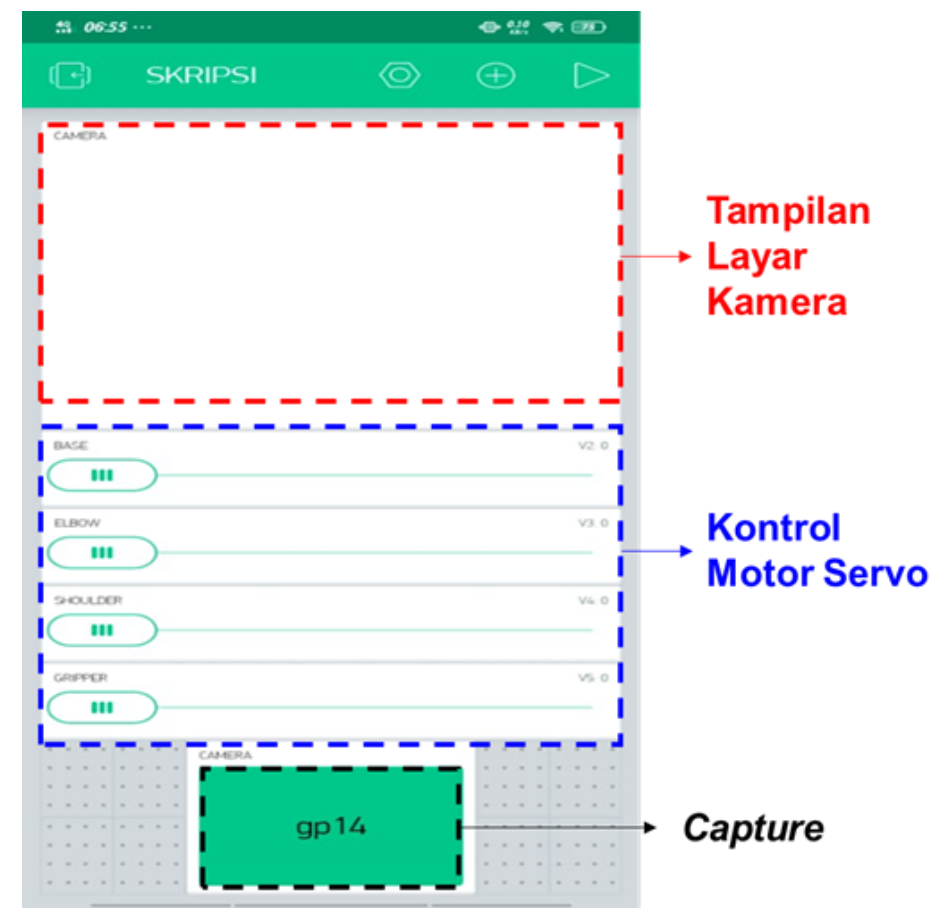

Gambar 7. Perangkat Antarmuka Aplikasi Lengan Robot

Gambar 7 menunjukkan tampilan aplikasi Blynk yang dioperasikan melalui smartphone. Fungsi layar kamera adalah untuk menampilkan hasil foto dari proses pemindahan barang sedangkan layar kontrol motor servo berfungsi untuk melakukan pengaturan terhadap pergerekan motor bagian bawah, bahu, siku dan pencengkram. Selanjutkan tombol gp14 berfungsi untuk melakukan pengambilan gambar dalam proses perpindahan menggunakan modul ESP 32 CAM. 


\subsection{Prototipe Lengan Robot}

Prototipe lengan robot ditunjukan pada gambar 8 dan gambar 9. Struktur dari fisik robot menggunakan bahan plastik $3 D$ printing, rangkaian pengendali seperti rangkaian mekanik, perangkat penunjang disusun sesuai dengan fungsi dan dikoneksikan menggunakan kabel jenis AWG-22 dengan kode warna yang telah disesuaikan

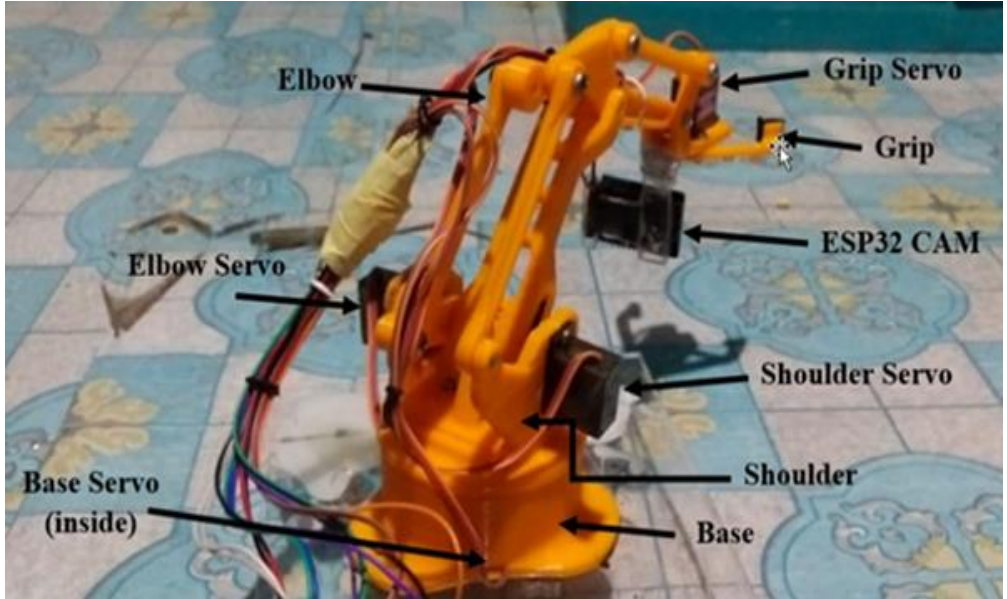

(a)

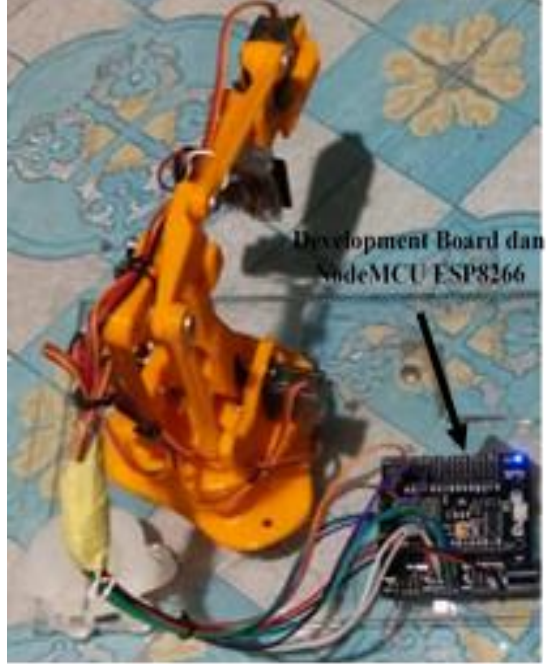

b)

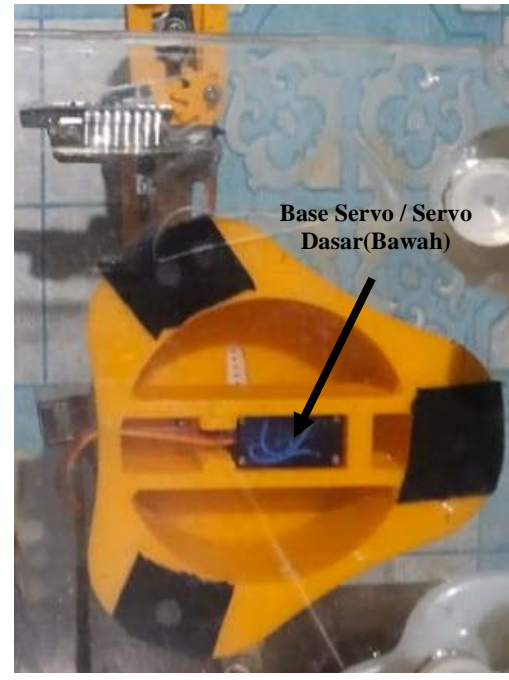

(c)

Gambar 8. Prototype Lengan Robot; (a) Tampak Samping, (b) Tampak Atas, (c) Tampak Bawah

\subsection{Pengujian Sistem}

Pengujian sistem ini dilakukan setelah proses dari perancangan dilakukan. Pengujian ini berfungsi untuk mengetahui akurasi dari prototype yang telah dirancang dan direalisasikan. Adapun pengujian sistem dilakukan dengan mengamati beberapa parameter antara lain pengujian jarak jangkauan pengendalian, pengujian monitoring kamera dan video selanjutnya adalah pengujian waktu dan kecepatan proses pemidahan barang dari satu posisi ke posisi lain menggunakan lengan robot yang telah dirancang. Pengujian jarak antara smartphone dengan lengan robot bertujuan untuk mengetahui berapa jarak jangkauan smartphone dengan lengan robot menggunakan media transmisi WiFi/ internet. Pengujian ini dilakukan dengan dua kondisi, yaitu pengujian jarak tanpa penghalang dan pengujian jarak dengan penghalang. Hasil pengujian jarak dari prototyope lengan robot ditunjukkan pada Tabel 2. 
Tabel 2. Pengujian Jarak

\begin{tabular}{ccr}
\hline Jarak & Tanpa Penghalang & Dengan Penghalang \\
\hline 1 meter & Terhubung & Terhubung \\
5 meter & Terhubung & Terhubung \\
10 meter & Terhubung & Terhubung \\
15 meter & Terhubung & Terhubung \\
20 meter & Terhubung & Tidak Terhubung \\
25 meter & Tidak Terhubung & Tidak Terhubung \\
\hline
\end{tabular}

Tabel 2 menunjukkan hasil pengujian yang telah dilakukan dengan dua kondisi yang ditetapkan. Untuk mengendalikan prototipe lengan robot sebagai pemindah barang menggunakan aplikasi pengendali tanpa penghalang dengan menggunakan media transmisi wifi/ internet, jarak terjauh prototipe alat pemindah barang yang dapat terhubung dengan smartphone adalah sejauh 20 meter. Apabila jarak lebih dari 20 meter maka koneksi wifi/ internet melemah, bahkan tidak dapat terhubung. Apabila menggunakan penghalang yaitu tembok dengan menggunakan media transmisi module wifi/ internet jarak terjauh prototipe lengan robot sebagai pemindah barang yang dapat terhubung dengan smartphone adalah sejauh 15 meter. Apabila jarak lebih dari 15 meter maka koneksi wifi/ internet melemah, bahkan tidak dapat terhubung. Tahapan selanjutnya yaitu melakukan uji perekaman video dan pengambilan gambar menggunakan ESP 32 CAM. Hasil dari proses pengujian modul ESP 32 CAM ditunjukkan pada gambar 9.

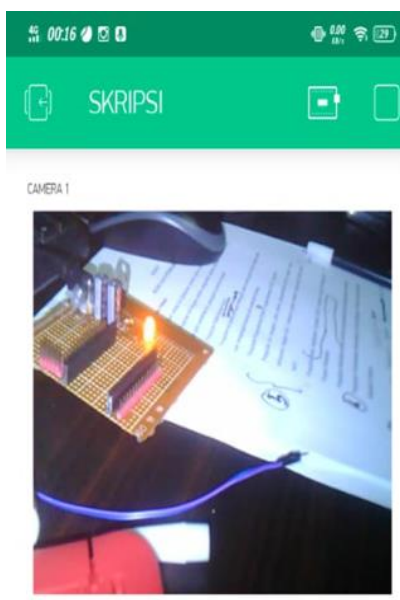

Gambar 9. Hasil Pengujian Pengambilan Gambar menggunakan ESP 32 CAM

Selanjutnya, dilakukan pengujian waktu dan kecepatan lengan robot dalam pemindahan barang dari satu tempat ke tempat lain. Pengujian ini diterapkan untuk 5 bentuk objek atau benda yang berbeda dari segi bentuk dan beratnya. Setelah itu, dilakukan proses pengamatan terhadap kecepatan dan waktu pemindahan dari masing-masing benda yang digunakan seperti yang ditunjukkan pada gambar 10 . 


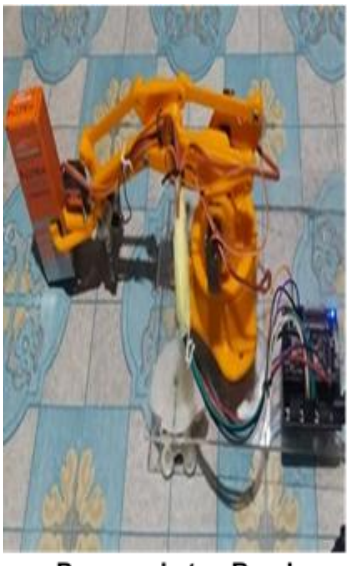

Pengangkatan Benda
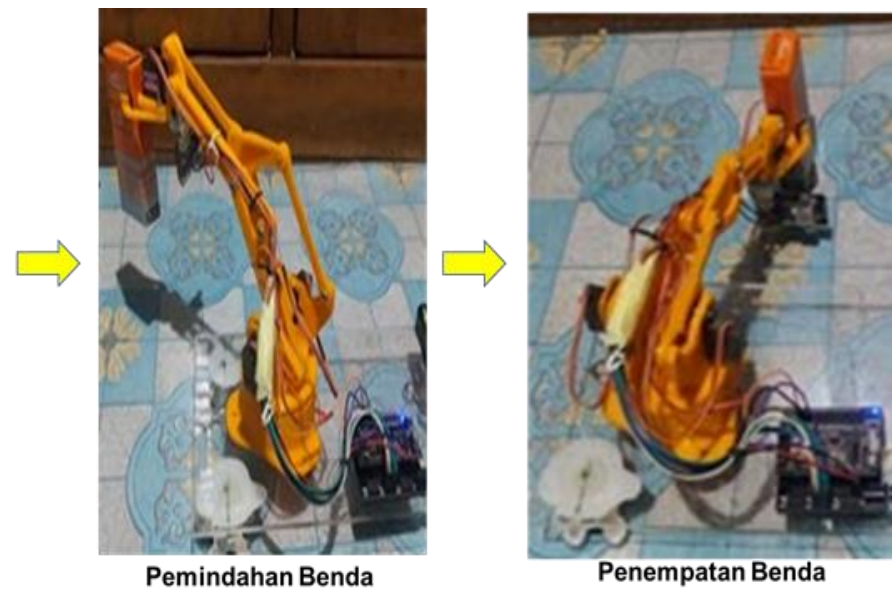

Gambar 10 . Tahapan Kerja dari Lengan Robot

Tabel 3. Hasil Pengujian Kinerja Lengan Robot

\begin{tabular}{|c|c|c|c|c|c|c|}
\hline $\begin{array}{c}\text { Nama Objek/ } \\
\text { Benda }\end{array}$ & Dimensi & Berat & Jarak & Kondisi & Waktu & Kecepatan \\
\hline Motor Servo SG90 & $2.2 \times 2.2 \times 1.2 \mathrm{~cm}^{3}$ & 12.6 gram & $25 \mathrm{~cm}$ & Terangkat & 37 detik & $0.0068 \mathrm{~m} / \mathrm{s}$ \\
\hline Lem Power Glue & $2.4 \times 2.2 \times 10 \mathrm{~cm}^{3}$ & 20 gram & $25 \mathrm{~cm}$ & Terangkat & 46 detik & $0.0054 \mathrm{~m} / \mathrm{s}$ \\
\hline Baterai $3.7 \mathrm{~V}$ & $6.5 \times 1.8 \times 3 \mathrm{~cm}^{3}$ & 36.1 gram & $25 \mathrm{~cm}$ & $\begin{array}{c}\text { Tidak } \\
\text { Terangkat }\end{array}$ & - & - \\
\hline
\end{tabular}

Berdasarkan Tabel 3 dapat dilihat bahwa lengan robot akan mengalami kegagalan dalam pencengkraman objek apabila permukaan objek yang memiliki bobot cukup besar. Beban maksimum yang mampu diangkat oleh lengan robot sebesar 20 gram dengan dimensi $2.4 \times 2.2 \times 10 \mathrm{~cm}^{3}$. Dari Percobaan yang sudah dilakukan diketahui bahwa kecepatan pada saat pengujian berbeda-beda. Beban berpengaruh pada kekuatan motor sehingga mempengaruhi laju kecepatan lengan. Perbedaan kecepatan juga dapat disebabkan dari kekuatan material bahan dari lengan robot, hal ini dapat dilihat dari perbedaan yang terjadi pada saat percobaan mengangkat beban yang lebih berat dari 20 gram lengan robot tidak dapat mengangkat beban.

\section{PENUTUP}

Pada penelitian ini prototype sistem pengendalian lengan robot berbasis Internet Of Things (IoT) telah berhasil dirancang dan direalisasikan. Dari hasil pengujian didapatkan jarak terjauh dari prototipe alat pemindah barang yang dapat terhubung tanpa penghalang dengan smartphone adalah sejauh 20 meter sedangkan dengan penghalang tembok jarak terjauh prototipe lengan robot sebagai pemindah barang yang dapat terhubung dengan smartphone adalah sejauh 15 meter. Selanjutnya, lengan robot dapat mengangkat beban dengan bobot maksimal yaitu 20 gram dengan dimensi 2.4 × $2.2 \times 10 \mathrm{~cm} 3$. Berdasarkan hasil pengujian pemindahan barang pada jarak $25 \mathrm{~cm}$ diperoleh waktu pemindahan 33 detik sedangkan kecepatan tercepat pemindahan barang yaitu $0.0054 \mathrm{~m} / \mathrm{s}$. Beban berpengaruh pada kekuatan motor sehingga mempengaruhi laju kecepatan lengan. Perbedaan kecepatan juga dapat disebabkan dari kekuatan material bahan dari lengan robot. Untuk itu perlu dilakukan pengembangan lebih lanjut terhadap prototipe lengan robot yang diusulkan dengan menggunakan bahan yang memiliki material lebih baik dan pengaturan kecepatan motor yang dapat disesuaikan dengan beban yang akan diangkat.

\section{UCAPAN TERIMAKASIH}

Penulis menyampaikan terima kasih kepada Universitas Trisakti dan Sekolah Tinggi Teknologi Indonesia yang telah mendukung terlaksananya kegiatan penelitian ini.

\section{DAFTAR PUSTAKA}


[1] Sisinni, E., Saifullah, A., Han, S., Jennehag, U. and Gidlund, M., "Industrial internet of things: Challenges, opportunities, and directions," IEEE Transactions on Industrial Informatics, vol. 14, no. 11, pp. pp.4724-4734, 2018.

[2] Wu, D., Shi, H., Wang, H., Wang, R. and Fang, H., "A feature-based learning system for Internet of Things applications," IEEE Internet of Things Journal, vol. 6, no. 2, pp. pp.1928-1937, 2018.

[3] Sun, T., Yang, S. and Lian, B., Finite and instantaneous screw theory in robotic mechanism, Springer Nature, 2020.

[4] Dewi, N.K., Mulyana, I., Putra, A.S. and Radita, F.R., "Konsep Robot Penjaga Toko Di Kombinasikan Dengan Pengendalian Virtual Reality (VR) Jarak Jauh," IKRA-ITH INFORMATIKA: Jurnal Komputer dan Informatika, vol. 5, no. 1, pp. pp.33-38, 2021.

[5] Causo, A., Durham, J., Hauser, K., Okada, K. and Rodriguez, A., Advances on Robotic Item Picking, Springer International Publishing, 2020.

[6] Xiang, W. and Yan, S., "Dynamic analysis of space robot manipulator considering clearance joint and parameter uncertainty: Modeling, analysis and quantification.," Acta Astronautica, vol. 169, pp. pp.158$169,2020$.

[7] Nubert, J., Köhler, J., Berenz, V., Allgöwer, F. and Trimpe, S., "Safe and fast tracking on a robot manipulator: Robust mpc and neural network control," IEEE Robotics and Automation Letters, vol. 5, no. 2, pp. pp.3050-3057, 2020.

[8] Tringali, A. and Cocuzza, S., "Globally optimal inverse kinematics method for a redundant robot manipulator with linear and nonlinear constraints," Robotics, vol. 9, no. 3, p. 61, 2020.

[9] Prasetyawan, P., Ferdianto, Y., Ahdan, S. and Trisnawati, F., "Pengendali Lengan Robot Dengan Mikrokontroler Arduino Berbasis Smartphone," J. Tek. Elektro ITP, vol. 7, no. 2, pp. pp.104-109, 2018.

[10] A. Ekayana, "Rancang Bangun Prototype Sistem Kendali Lengan Robot Pemindah Barang Menggunakan Interface Wireless $2.4 \mathrm{GHz}, "$ JST (Jurnal Sains dan Teknologi), vol. 6, no. 1, pp. pp 116 - 125, 2017.

[11] Santoso, I., Adiwisastra, M.F., Simpony, B.K., Supriadi, D. and Purnia, D.S., "Impelementasi NodeMCU dalam Home Automation dengan Sistem Kontrol Apkikasi Blynk," Swabumi, vol. 9, no. 1, pp. 32-40, 2021.

[12] Debauche, O., Mahmoudi, S., Marzak, A., Manneback, P. and Lebeau, F., "Smart nest box : IoT based nest monitoring in artificial cavities.," in In 2020 3rd International Conference on Advanced Communication Technologies and Networking (CommNet), 2020. 